Article

\title{
Lithium Content of 160 Beverages and Its Impact on Lithium Status in Drosophila melanogaster
}

\author{
Ulrike Seidel ${ }^{1, *}$, Katharina Jans ${ }^{1}$, Niklas Hommen ${ }^{2}$, Ignacio R Ipharraguerre ${ }^{1} \oplus$, Kai Lüersen ${ }^{1}$, \\ Marc Birringer $^{2}$ and Gerald Rimbach ${ }^{1}$ \\ 1 Institute of Human Nutrition and Food Science, University of Kiel, 24118 Kiel, Germany; \\ jans@foodsci.uni-kiel.de (K.J.); ipharraguerre@foodsci.uni-kiel.de (I.R.I.); luersen@foodsci.uni-kiel.de (K.L.); \\ rimbach@foodsci.uni-kiel.de (G.R.) \\ 2 Department of Nutritional, Food and Consumer Sciences, Fulda University of Applied Sciences, \\ 36037 Fulda, Germany; niklas.hommen@oe.hs-fulda.de (N.H.); marc.birringer@oe.hs-fulda.de (M.B.) \\ * Correspondence: seidel@foodsci.uni-kiel.de; Tel.: +49-0431-880-5334
}

Received: 21 May 2020; Accepted: 11 June 2020; Published: 17 June 2020

\begin{abstract}
Lithium (Li) is an important micronutrient in human nutrition, although its exact molecular function as a potential essential trace element has not yet been fully elucidated. It has been previously shown that several mineral waters are rich and highly bioavailable sources of Li for human consumption. Nevertheless, little is known about the extent in which other beverages contribute to the dietary Li supply. To this end, the Li content of 160 different beverages comprising wine and beer, soft and energy drinks and tea and coffee infusions was analysed by inductively coupled plasma mass spectrometry (ICP-MS). Furthermore, a feeding study in Drosophila melanogaster was conducted to test whether Li derived from selected beverages changes Li status in flies. In comparison to the average $\mathrm{Li}$ concentration in mineral waters $(108 \mu \mathrm{g} / \mathrm{L}$; reference value), the $\mathrm{Li}$ concentration in wine $(11.6 \pm 1.97 \mu \mathrm{g} / \mathrm{L})$ and beer $(8.5 \pm 0.77 \mu \mathrm{g} / \mathrm{L})$, soft and energy drinks $(10.2 \pm 2.95 \mu \mathrm{g} / \mathrm{L})$, tea $(2.8 \pm 0.65 \mu \mathrm{g} / \mathrm{L})$ and coffee $(0.1 \pm 0.02 \mu \mathrm{g} / \mathrm{L})$ infusions was considerably lower. Only Li-rich mineral water $(\sim 1600 \mu \mathrm{g} / \mathrm{L})$ significantly increased Li concentrations in male and female flies. Unlike mineral water, most wine and beer, soft and energy drink and tea and coffee samples were rather Li-poor food items and thus may only contribute to a moderate extent to the dietary Li supply. A novelty of this study is that it relates analytical Li concentrations in beverages to Li whole body retention in Drosophila melanogaster.
\end{abstract}

Keywords: fruit fly; food database; beverages; trace elements

\section{Introduction}

The average annual beverage intake of the German population in 2018 was estimated to be approximately 760 litres [1]. In terms of consumption, coffee is the most important beverage, followed by mineral water, soft drinks, beer, tea and wine, as summarized in Figure 1. Beverages are the major source of water intake [2] but may also significantly contribute to the supply of minerals and trace elements [3,4].

$\mathrm{Li}$ is an important trace element with multiple potential health benefits. Dietary Li exposure is associated with a lower risk of dementia [5,6], Alzheimer disease mortality [7] and suicide risk [8-10]. Furthermore, there is increasing experimental evidence that Li may positively affect bone health [11] and muscle function [12]. Studies in model organisms, including C. elegans [13] and Drosophila melanogaster [14], suggest that Li may improve life and healthspan. 


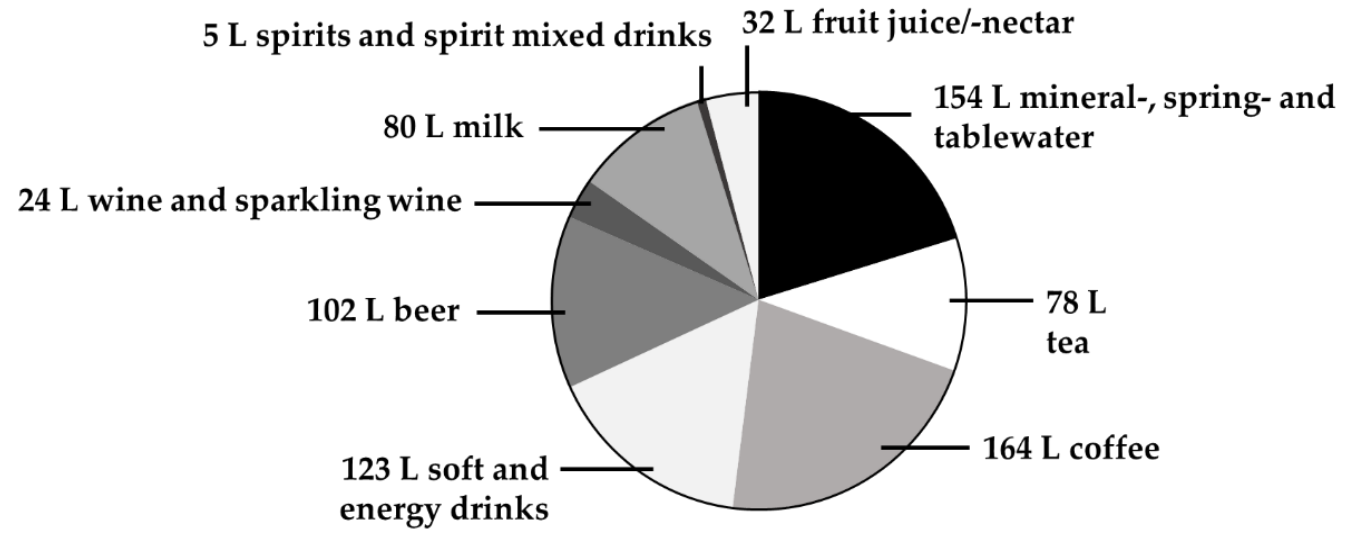

Figure 1. Annual per capita consumption of beverages (in litres) in Germany in 2018. Data are obtained from Statista [1]. Primary sources: German Wine Institute, Federal Office for Agriculture and Food, Associations of the German Beverage Industry. Obtained on 10 March 2020.

Unlike essential trace elements such as iron, zinc, copper, manganese, selenium, iodine little is known about the Li status of the general European population. This is partly related to the fact that there are so far no reliable biochemical biomarkers (e.g., Li-sensitive proteins/enzymes) which at least partly reflect the dietary Li supply. Thus, the Li status in humans is estimated either by Li concentration in blood (plasma or serum) or urinary Li excretion. Similar to sodium, Li homeostasis is adaptively regulated by the kidney and $\mathrm{Li}$ is mainly reabsorbed in the proximal tubule $[15,16]$. However, even at very low dietary intake, filtered $\mathrm{Li}$ is not fully reabsorbed [17] and there could be a minimum dietary need for Li to ensure a positive Li balance.

Several tap and mineral waters have been reported to be important and highly bioavailable sources of dietary $\mathrm{Li}[18,19]$. In this context, our recent data [20] suggest that the consumption of $600 \mathrm{~mL}$ of Li-rich mineral water may already meet the provisional dietary recommendation for Li set to $1000 \mu \mathrm{g} /$ day for a $70-\mathrm{kg}$ adult $(14.3 \mu \mathrm{g} / \mathrm{kg}$ body weight) [21]. However, $\mathrm{Li}$ is yet not considered officially as an essential trace element. Therefore, the dietary Li recommendation according to Schrauzer [21] cannot fully be applied in dietary practice [22]. Little is known about the extent to which other frequently consumed beverages, such as tea and coffee, soft and energy drinks and beer and wine contribute to the Li supply in humans. These beverages were chosen, since together with the consumption of mineral water, they cover approximately $85 \%$ of the liquid intake in the German population. Furthermore, we addressed the question of which dietary Li concentration is needed to increase tissue Li concentration in Drosophila melanogaster, a versatile model organism in food and nutrition research $[23,24]$. Thus, a major aim of this study is to relate analytical results from a Li food database to Li whole body retention in fruit flies.

\section{Materials and Methods}

\subsection{Sampling of Beverages and Lithium Analysis}

Sampling took place between May 2018 and November 2019. Beverages were purchased from supermarkets, drinks markets, and kiosks in the cities of Kiel (Schleswig-Holstein) and Fulda (Hesse), Germany. Coffee and tea were purchased in their dry form as 250-500 g ground coffee packages and commercially available tea bags, respectively. Coffee and tea infusions were prepared under standardized conditions: $7 \mathrm{~g}$ coffee ground was placed in a porcelain filter covered with unbleached filter paper and brewed with $150 \mathrm{~mL}$ deionized water at $90^{\circ} \mathrm{C}$. The tea bags (on average $2.1 \mathrm{~g} / \mathrm{bag}$; $1.75-3.0 \mathrm{~g} / \mathrm{bag}$ ) were brewed with $250 \mathrm{~mL}$ deionised water for $7 \mathrm{~min}$ and a starting temperature of $98^{\circ} \mathrm{C}$. Five-millilitre aliquots of the corresponding samples were dispensed into polyethylene falcon tubes with screw caps (Sarstedt, Nuembrecht, Germany) and stored at room temperature until Li 
analysis. Li concentrations in our 160 samples were determined via inductively coupled plasma mass spectrometry (ICP-MS) as summarized in Table 1.

Table 1. Lithium analysis by inductively coupled plasma mass spectrometry (ICP-MS).

\begin{tabular}{ll}
\hline Experimental Conditions & \\
\hline Apparatus & ICAPQ (Thermo Fisher Scientific Waltham) \\
& DIN EN ISO 17294-2: 2017-01 \\
Method & Conducted by SYNLAB Analytics and Service, \\
& Jena, Germany \\
Sample Dilution & 1 to $10(2 \%(v / v))$ nitric acid \\
Internal Standard & Rhodium $(2 \mu \mathrm{g} / \mathrm{L})$ \\
Limit of Detection (LOD) & $<0.002 \mu \mathrm{g} / \mathrm{L}$ \\
Limit of Quantification (LOQ) & $0.003 \mu \mathrm{g} / \mathrm{L}$ \\
Recovery & $98.8 \%(n=6)$ \\
Intra-Day Precision, Coefficient of Variation & $0.7 \%(n=6)$ \\
\hline
\end{tabular}

\subsection{Lithium Feeding of Fruit Flies}

Stocks of the Drosophila melanogaster wild-type strain $w^{1118}$ (Bloomington Drosophila Stock Center \#5905, Indiana University, Bloomington, IN, USA) were maintained at $25{ }^{\circ} \mathrm{C}$ and $60 \%$ humidity under a 12/12 h light/dark cycle on standard Caltech fly medium (CT medium: 5.5\% dextrose, 3.0\% sucrose, $6.0 \%$ corn meal, $2.5 \%$ inactive dry yeast, $1.0 \%$ agar, $0.3 \%$ nipagin and $0.3 \%$ propionic acid) according to [25]. For Li supplementation experiments, 250-300 synchronized Drosophila eggs were maintained in culture bottles filled with $25 \mathrm{~mL} \mathrm{CT}$ medium, and animals were raised under standard culture conditions. Three days after exclusion, the adult flies were separated by sex and transferred to a sugar yeast (SY)-based medium prepared according to Ashburner [26]. For the control groups, SY was prepared by using Li-free deionized water $(\mathrm{CON})$. For the treatment groups, diets were modified by using three different sparkling mineral waters namely Trendic (Marinus spring, Germany) with low Li, Gerolsteiner (Gerolsteiner spring, Germany) with medium Li and Perling (Tiefen spring, Germany) with high Li concentrations instead of deionized water (Table 2). The analyzed Li concentrations of the three mineral waters slightly differed from our previously reported values [20] which may be related to batch to batch variations. Furthermore, five beverages containing the highest amount of Li within the selected beverage categories-wine (Rioja/Tempranillo Joven, Bilbao, Spain), beer (Hochstift Pils, tapped at Fulda brewery, Germany), soft/energy drink (Acai 28 Black, Wecker, Luxembourg), tea (Lord Nelson Rooibos tea, Seevetal, Germany) and coffee (Tchibo "Privat" Coffee, Guatemala) were chosen for replacement of deionized water in the fly medium. The experimental design is described in Table 2. Again, Li values in beverages used for the feeding study may slightly differ from Li values analysed as a part of the initial beverage screening since another batch of the bottled beverage or a freshly prepared tea and coffee infusion was used. For feeding wine, only $50 \%$ of the fluid fraction was replaced by "Rioja/Tempranillo" to reduce the ethanol content in the fly medium. The final Li concentrations of the corresponding fly diets are shown in Table 2.

After consuming their respective diets for seven days, flies were harvested, transferred to empty bottles and kept under standard conditions for $2 \mathrm{~h}$ for gastric emptying. After the first hour of starvation, the bottle was exchanged to reduce coprophagy. Subsequently, the flies were stored at $-80^{\circ} \mathrm{C}$. The body weights of $95-100$ animals per treatment group were determined before their $\mathrm{Li}$ content was analysed by ICP-MS. 
Table 2. Experimental design of the feeding study in Drosophila melanogaster. Experimental diets were prepared using eight respective beverages and deionized water as control. Flies were fed the experimental diets for seven days $(n=4-8$ independent experiments per group, comprising 100 flies/group).

\begin{tabular}{lccc}
\hline Group & Respective Beverage & $\begin{array}{c}\text { Lithium Concentration } \\
\text { in Beverages }(\mu \mathrm{g} / \mathrm{L})\end{array}$ & $\begin{array}{c}\text { Lithium Concentrations } \\
\text { in Fly Diets }(\mu \mathrm{g} / \mathrm{L})\end{array}$ \\
\hline Control & Deionised water & $<0.003$ & 14.8 \\
Mineral Water & Trendic & 1.7 & 20.8 \\
Low Li & Gerolsteiner & 209.7 & 191.0 \\
Medium Li & Perling & 1611.9 & 1562.0 \\
High Li & 51.2 & 39.2 \\
Wine & Rioja/Tempranillo Joven & 19.9 & 27.4 \\
Beer & Hochstift Pils & 103.2 & 89.2 \\
Soft/Energy Drink & Acai 28 Black & 9.5 & 24.9 \\
Tea & Lord Nelson Rooibos tea & 0.4 & 12.4 \\
Coffee & Tchibo “Privat" Coffee & & \\
\hline
\end{tabular}

\subsection{Statistical Analysis}

Statistical analyses were conducted using GraphPad PRISM software (San Diego, CA, USA) and IBM SPSS Statistics 24 (Ehningen, Germany). For bivariate analysis, Pearson's correlation coefficient and linear regression were calculated. For statistical hypothesis tests, groups were analysed for normality of the distribution (Kolmogorov-Smirnov and Shapiro-Wilk tests). In the case of normally distributed data, Levene's test was conducted to assess the homogeneity of variances. If the null hypothesis was rejected (Levene's test not significant), one-way analysis of variance (ANOVA) with a one-sided Tukey test as post hoc analysis was performed. If the null hypothesis was confirmed (Levene's test is significant), the Games-Howell post hoc test was used. In the absence of normally distributed data, the data were transformed into normally distributed data, and a post hoc test was chosen as described before.

\section{Results and Discussion}

\subsection{Analysis of Beverages}

We previously analysed the Li content of almost all mineral and medicinal waters available on the German market [20]. The mean Li concentration in the analysed waters was $108 \mu \mathrm{g} / \mathrm{L}$ and set as the reference value. Compared to mineral water, the average Li concentrations in wine and beer, soft and energy drinks and tea and coffee infusions were many times lower (Table 3). The mean analysed Li concentrations in soft drinks, beer and wine $(\sim 10 \mu \mathrm{g} / \mathrm{L})$ were significantly higher compared to tea and coffee but still rather low compared to mineral water (Tables 3-6). One soft drink, namely, Acai 28 Black $(105 \mu \mathrm{g} \mathrm{Li} / \mathrm{L})$, exhibited $\mathrm{Li}$ values comparable to the mean Li values found in mineral water (Table 5).

Table 3. (A) Lithium (Li) concentrations in different beverage categories. Li content was analysed in wine $(n=39)$ and beer $(n=42)$, soft and energy drinks $(n=39)$ as well as tea $(n=20)$, coffee $(n=20)$. The average $\mathrm{Li}$ content of mineral water $(=108 \mu \mathrm{g} / \mathrm{L})$ was set as a reference value. Li concentrations were measured by inductively coupled plasma mass spectrometry (ICP-MS).

\begin{tabular}{lccccc}
\hline Beverage Categories & $\mathbf{N}$ & Min Li $(\mu \mathrm{g} / \mathrm{L})$ & Max Li $(\mu \mathrm{g} / \mathrm{Li})$ & $\begin{array}{c}\text { Median Li } \\
(\mu \mathrm{g} / \mathrm{L})\end{array}$ & $\begin{array}{c}\text { Mean Li }(\mu \mathrm{g} \\
\mathbf{L i} / \mathrm{L} \pm \mathrm{SEM})\end{array}$ \\
\hline Mineral Water * & 381 & 0.6 & 1723.8 & 31.4 & $107.6 \pm 11.53^{\mathrm{a}}$ \\
Wine & 39 & 2.0 & 48.1 & 6.0 & $11.6 \pm 1.97^{\mathrm{b}}$ \\
Beer & 42 & 1.9 & 19.9 & 8.3 & $8.5 \pm 0.77^{\mathrm{b}}$ \\
Soft/Energy Drinks & 39 & 0.5 & 104.8 & 3.9 & $10.2^{ \pm} \pm 2.95^{\mathrm{b}}$ \\
Tea & 20 & 0.3 & 9.9 & 1.4 & $2.8^{\mathrm{c}} \pm 0.65^{\mathrm{c}}$ \\
Coffee & 20 & $<0.003$ & 0.4 & 0.1 & $0.1 \pm 0.02^{\mathrm{d}}$ \\
\hline
\end{tabular}

* Reference value, according to Seidel et al. (2019) [17]. Different letters indicate significant differences $(p \leq 0.05)$ in mean $\mathrm{Li}$ concentrations between the tested beverage categories. 
Table 4. Lithium concentrations ( $\mu \mathrm{g} \mathrm{Li} / \mathrm{L}$ ) of beer and wine. Wine samples were grouped in red and white wine. Li concentrations were measured by inductively coupled plasma mass spectrometry (ICP-MS).

\begin{tabular}{|c|c|}
\hline Individual Beverages & $\mu \mathrm{g} \mathrm{Li} / \mathrm{L}$ \\
\hline \multicolumn{2}{|l|}{ Wine } \\
\hline Red wine (Grape variety, producing area, crop year, wine grower) & 17.0 \\
\hline Cabernet Sauvignon (Pays d’Oc, France, 2018, Grand Verdier) & 14.1 \\
\hline Cabernet Sauvignon (Valle Central, Chile, 2018) & 3.1 \\
\hline Cabernet Sauvignon (Valle Central, Chile, 2018, Espiritu de Chile) & 14.8 \\
\hline Cabernet Sauvignon (Valle Central, Chile, 2018, Valmaduro) & 13.5 \\
\hline Merlot (Bordeaux, France, 2018, BDX) & 6.2 \\
\hline Merlot (Sicily, Italy, 2017, Canti) & 25.7 \\
\hline Merlot (Sicily, Italy, 2018, Lato Mare) & 13.1 \\
\hline Merlot / Cabernet Sauvignon (Western Cape, South Africa, 2018, Fairglobe) & 4.8 \\
\hline Pinot Noir (Baden, Germany, 2018) & 2.4 \\
\hline Rioja/Tempranillo (Bilbao, Spain, 2017, Ramon Bilbao) & 48.1 \\
\hline Rioja/Tempranillo (Rioja, Spain, 2018, La Tenda) & 45.0 \\
\hline Rioja/Tempranillo (Rioja, Spain, 2015, Ramon Lopez Murillo) & 43.6 \\
\hline Pinot Noir (Baden, Germany, 2017, Diersburger Fuersteneck) & 2.3 \\
\hline Pinot Noir (Baden, Germany, 2018, Juergen von der Mark) & 3.6 \\
\hline Pinot Noir (Rheinhessen, Germany, 2018, Rotkaeppchen) & 15.2 \\
\hline White wine (Grape variety, producing area, crop year, wine grower) & 8.3 \\
\hline Chardonnay (Eltville, France,2018, Blanchet) & 5.9 \\
\hline Chardonnay (France, 2018, Grand Sud) & 8.4 \\
\hline Chardonnay (Garda, Italy, 2018, Mario Collina) & 2.6 \\
\hline Chardonnay (South Eastern, Australia, 2018, Cimarosa) & 21.0 \\
\hline Pinot Blanc (Baden, Germany, 2018) & 2.8 \\
\hline Pinot Blanc (Mosel, Germany, 2018, “Moselland-Akzente”) & 5.0 \\
\hline Pinot Blanc (Pfalz, Germany) & 4.0 \\
\hline Pinot Blanc (Rheinhessen, Germany, 2018) & 6.0 \\
\hline Pinot Grigio (Delle Venezie, Italy, 2018, Giulio Pasotti) & 3.7 \\
\hline Pinot Grigio (Delle Venezie, Italy, 2018, Pinetta) & 3.1 \\
\hline Pinot Grigio (Provincia di Pavia, Italy, 2018, Canti) & 14.7 \\
\hline Pinot Grigio (Romania, 2018, Veronica Gheorghiu) & 5.5 \\
\hline Riesling (Pfalz, Germany, 2018, Hettinger) & 9.3 \\
\hline Riesling (Pfalz, Germany, 2018, Mussbacher Eselshaut) & 5.2 \\
\hline Sauvignon Blanc (Marlborough, New Zealand, 2018) & 4.8 \\
\hline Sauvignon Blanc (Marlborough, New Zealand, 2019, Cimarosa) & 4.4 \\
\hline Sauvignon Blanc (Western Cape, South Africa, 2018, Nederburg) & 11.0 \\
\hline Sauvignon Blanc (Western Cape, South Africa, 2018, Two Oceans-Vineyard Selection) & 9.9 \\
\hline Mueller-Thurgau (Rheinhessen, Germany, 2018) & 11.5 \\
\hline Mueller-Thurgau (Baden, Germany, 2018) & 2.5 \\
\hline Mueller-Thurgau (Rheinhessen, Germany, 2018, Westhofener Bergkloster) & 10.3 \\
\hline Riesling (Rheinhessen, Germany, 2018, “Hochgewaechs") & 40.2 \\
\hline Riesling (Wuerttemberg, Germany, 2018, “Suess and Fruchtig") & 3.8 \\
\hline
\end{tabular}


Table 4. Cont.

\begin{tabular}{|c|c|}
\hline Individual Beverages & $\mu \mathrm{g} \mathrm{Li} / \mathrm{L}$ \\
\hline \multicolumn{2}{|l|}{ Beer } \\
\hline Astra, “Urtyp” & 9.0 \\
\hline Augustiner brew Munich, "Edelstoff" & 2.3 \\
\hline Becks pilsener & 6.7 \\
\hline Bitburger pils & 12.7 \\
\hline Brinkhoffs pils & 7.2 \\
\hline Budweiser & 4.6 \\
\hline Corona, extra & 11.8 \\
\hline Einbecker pils & 8.3 \\
\hline Erdinger weissbeer & 1.9 \\
\hline Faust lager "hell" & 10.3 \\
\hline Faust pils & 11.5 \\
\hline Flensburger pilsener & 7.8 \\
\hline Franziskaner wheat beer & 3.4 \\
\hline Heineken pils & 5.0 \\
\hline Hochstift pils & 17.9 \\
\hline Hochstift pils drawn, Esperanto & 19.9 \\
\hline Holsten pilsener & 9.9 \\
\hline Jever pilsener & 10.3 \\
\hline Krombacher pils & 5.3 \\
\hline Licher pils & 8.5 \\
\hline Oettinger pils & 2.8 \\
\hline Pilgerstoff, "Vollbier" & 12.9 \\
\hline Schlappeseppel pils & 2.9 \\
\hline Schwarzer Hahn, drawn, Esperanto & 19.7 \\
\hline Tegernseer, special & 2.5 \\
\hline Uglens Julebryg & 10.8 \\
\hline Veltins pils & 3.2 \\
\hline Warsteiner pilsener & 18.2 \\
\hline Will Brew pils, deluxe & 8.7 \\
\hline Will Brew wheat beer, drawn Esperanto & 8.8 \\
\hline Allgaeuer Bueble beer & 3.0 \\
\hline Distelhaeuser pils & 2.7 \\
\hline Fuldaer "Stadtbraeu" pils & 16.4 \\
\hline Hirschbraeu/Adlerkoenig, "Urtyp, hell” & 2.4 \\
\hline Koenig pilsener & 4.8 \\
\hline Koestritzer "Kellerbier" & 7.7 \\
\hline Luebzer pilsener & 8.2 \\
\hline Moenchshof pilsener & 14.2 \\
\hline Noerten-Hardenberger pils & 7.0 \\
\hline Rothaus “Tannenzaepfle” & 10.0 \\
\hline Schoefferhofer wheat beer & 6.3 \\
\hline Wernesgruener pilsener & 8.5 \\
\hline
\end{tabular}


Table 5. Lithium concentrations ( $\mu \mathrm{g} \mathrm{Li} / \mathrm{L}$ ) of soft and energy drinks, grouped in cola and cola mixed drinks, energy drinks, lemonades and other soft drinks. Li concentrations were measured by inductively coupled plasma mass spectrometry (ICP-MS).

\begin{tabular}{|c|c|}
\hline Individual Beverages & $\mu \mathrm{g} \mathrm{Li} / \mathrm{L}$ \\
\hline \multicolumn{2}{|l|}{ Soft and Energy Drinks } \\
\hline Cola and Cola Mixed Drinks & 7.8 \\
\hline Afri Cola & 58.3 \\
\hline Coca Cola & 2.8 \\
\hline Coca Cola, life & 1.5 \\
\hline Coca Cola, light & 1.7 \\
\hline Coca Cola, zero & 2.0 \\
\hline Fritz Kola & 11.4 \\
\hline Mezzo Mix & 1.6 \\
\hline Pepsi Cola & 0.5 \\
\hline Pepsi, light & 0.5 \\
\hline Pepsi, Max & 12.1 \\
\hline Red Bull Cola & 3.9 \\
\hline Schwipp Schwapp & 3.1 \\
\hline Spezi & 2.5 \\
\hline Energy drinks & 23.7 \\
\hline Acai 28 Black, energy & 104.8 \\
\hline Cola Energy, zero & 12.8 \\
\hline Effect & 1.3 \\
\hline Red Bull & 10.2 \\
\hline Red Bull, zero & 9.5 \\
\hline Rockstar & 3.4 \\
\hline Lemonades & 8.5 \\
\hline Bionade, elderberry & 12.1 \\
\hline Deit & 8.6 \\
\hline Fanta & 14.1 \\
\hline Fanta, zero & 14.8 \\
\hline Fritz limo, citron & 12.7 \\
\hline Fritz spritz & 2.0 \\
\hline Granini “Die Limo”, citron & 2.6 \\
\hline Krombacher's "Fassbrause", elderberry & 4.7 \\
\hline Orangina, original & 2.8 \\
\hline Schweppes, bitterlemon & 7.7 \\
\hline Seven Up & 1.4 \\
\hline Sinalco & 21.1 \\
\hline Sprite & 1.4 \\
\hline Sprite, zero & 17.8 \\
\hline Veltins "Fassbrause" & 3.7 \\
\hline Vilsa, apple-orange & 8.7 \\
\hline Other soft drinks & 4.0 \\
\hline Kombucha & 7.8 \\
\hline Lipton, citron & 1.6 \\
\hline Pfanner ice tea, peach & 2.3 \\
\hline Punica Tea and Fruit, fruit-red & 4.1 \\
\hline
\end{tabular}


Table 6. Lithium concentrations ( $\mu \mathrm{g} \mathrm{Li/L)} \mathrm{of} \mathrm{tea} \mathrm{and} \mathrm{coffee} \mathrm{infusions.} \mathrm{Tea} \mathrm{samples} \mathrm{were} \mathrm{grouped} \mathrm{in}$ black and green, fruit and herbal tea. Li concentrations were measured by inductively coupled plasma mass spectrometry (ICP-MS).

\begin{tabular}{|c|c|}
\hline Individual Beverages & $\mu \mathrm{g} \mathrm{Li} / \mathrm{L}$ \\
\hline \multicolumn{2}{|l|}{ Tea } \\
\hline Black and green tea & 0.7 \\
\hline Fairglobe black tea, Darjeeling & 0.3 \\
\hline Lipton black tea "Yellow label" & 0.9 \\
\hline Lord Nelson green tea/sencha & 0.7 \\
\hline Teekanne Darjeeling & 0.8 \\
\hline Teekanne green tea & 1.0 \\
\hline Westminster black tea mix & 0.7 \\
\hline Messmer Darjeeling & 0.7 \\
\hline Fruit tea & 2.0 \\
\hline Lord Nelson bio fruit tea (hibiscus, apple, rose hip, orange, lemon) & 1.3 \\
\hline Westminster fruit tea (rose hip, hibiscus) & 2.3 \\
\hline Westminster rose hip & 2.3 \\
\hline Messmer fruit mix (apple, orange, lemon, elder berry, hibiscus, rose hip) & 1.5 \\
\hline Teekanne "Fruechtegenuss" (rose hip, hibiscus, apple, orange, elder berry, peppermint) & 2.5 \\
\hline Herbal tea & 5.7 \\
\hline Lord Nelson rooibos & 9.9 \\
\hline Teekanne South-African roiboos & 7.3 \\
\hline Westminster chamomile & 0.3 \\
\hline $\begin{array}{l}\text { Lord Nelson "Kraeuter pur" (peppermint, "elissa"ss, rooibos, fennel, chamomile, blackberry, } \\
\text { melissa, orange, lemon verbena) }\end{array}$ & 4.2 \\
\hline $\begin{array}{l}\text { Messmer, “Kraeuter pur" (peppermint, lemongrass, rooibos, fennel, chamomile, blackberry, } \\
\text { “elissa, orange, lemon verbena) }\end{array}$ & 5.1 \\
\hline Messmer roiboos & 8.7 \\
\hline $\begin{array}{l}\text { Teekanne "8 Kraeuter" (rooibos, blackberry, lemon verbena, peppermint, chamomile, fennel, } \\
\text { licorice, cinnamon) }\end{array}$ & 4.5 \\
\hline \multicolumn{2}{|l|}{ Coffee } \\
\hline Alnatura & $<0.003$ \\
\hline Dallmayr & 0.1 \\
\hline Eilles Gourmet Coffee & 0.2 \\
\hline Galavon Eduscho & 0.2 \\
\hline Idee Coffee & 0.2 \\
\hline Jacobs & $<0.003$ \\
\hline Lavazza & 0.2 \\
\hline Melitta "Auslese" & 0.0 \\
\hline Melitta "Auslese", classical-mild & 0.3 \\
\hline Melitta Coffee, harmony-mild & 0.1 \\
\hline Tchibo "Beste Bohne" & $<0.003$ \\
\hline Tchibo "Black and White" & 0.1 \\
\hline Tchibo "Der Herzhafte" & 0.2 \\
\hline Tchibo "Privat" Coffee & 0.4 \\
\hline Tchibo "Sana" & 0.1 \\
\hline Tchibo, "Feine Milde" & 0.1 \\
\hline Amoroy & 0.1 \\
\hline Gut and Guenstig & 0.1 \\
\hline Jacobs "Meisterroestung" & 0.1 \\
\hline Moevenpick & 0.2 \\
\hline
\end{tabular}

Although Li has not yet been considered to be an essential trace element, it mediates important functions in humans and animals [22,27]. Schrauzer recommended a provisional dietary Li intake of $1000 \mu \mathrm{g}$ per day [21]. Based on the present results, this intake cannot be achieved through the regular consumption of tea and coffee infusions, soft and energy drinks, beer and wine. Thus, most of these 
food items may per se have only a moderate impact on the Li supply in humans. However, it needs to be established in future studies whether and to what extent the Li concentration in foods and beverages will increase through biofortification. For instance, it has been shown that the Li concentration of mushrooms can be enhanced via Li supplementation in a dose-dependent manner [28]. Consumption of $100 \mathrm{~g}$ dry matter of these mushrooms would constitute approximately $70 \%$ of the provisional recommended dietary daily Li intake.

As unsweetened tea does not provide calories per se, tea could be an interesting candidate as far as biofortification strategies are concerned. In this context, Jian and co-workers suggest that Li-fortified medicinal teas may be used to enhance Li supply in humans [29]. Previously, they found that different tea types differ in their Li content [30]. The highest Li content was detected in an herbal Luobuma tea infusion $(71 \mu \mathrm{g} / \mathrm{L})$, whereas other types of green and black tea infusion, according to our present data, contained very little $\mathrm{Li}(0.09-0.53 \mu \mathrm{g} / \mathrm{L})$.

In the current study, coffee, as well as green, black and herbal tea infusions were prepared with deionized water devoid of Li. However, coffee and tea are normally brewed with public drinking water. Thus, the Li concentration of these two beverages largely depends on the Li concentration of the drinking water exhibiting substantial geographical and geological differences within and between countries [31]. Likewise, most of the analysed soft drinks contained rather low amounts of Li. Given that soft drinks are rich in sugar and/or artificial sweeteners, Li biofortification of soft drinks is not recommended. It is interesting to note that the lemon-lime flavoured soft drink 7-Up was supplemented with $5 \mathrm{mg} \mathrm{Li}$ as Li citrate per litre until 1948, as it was believed to cure alcohol-induced hangover symptoms [32]. Lithiated beverages were commonly offered in the beginning of the twentieth century, as they were believed to mediate health benefits [33].

Cola-based soft drinks are very popular worldwide [34]. Under the conditions investigated, most cola-containing drinks were rather poor in Li. Only one Cola-based soft drink (Afri Cola) contained a Li concentration $>50 \mu \mathrm{g} / \mathrm{L}$. Furthermore, excessive consumption of Cola-based drinks may impair Li status in humans, as previously reported [35]. The underlying mechanisms by which Cola drinks could impair Li status are not clear. One explanation could be that caffeine, which is highly present in cola and energy drinks as well as in coffee, promotes diuresis, which may be accompanied by increased renal losses of Li via urine.

So-called energy drinks contained on average $20.9 \pm 37.3 \mu \mathrm{g} \mathrm{Li} / \mathrm{L}$. One acai-containing energy drink (Acai 28 black, ca. $4 \%$ acai extract) was rather rich in $\mathrm{Li}(>100 \mu \mathrm{g} \mathrm{Li} / \mathrm{L})$. It has been previously reported that Acai pulp contains substantial concentrations of other trace elements, including iron, zinc, copper and manganese [36]. In addition to acai extract, Acai 28 black contains lemon juice concentrate, guarana and herb extracts, which possibly supply Li to this energy drink.

The average analysed $\mathrm{Li}$ concentration of $11.6 \pm 1.97 \mu \mathrm{g} / \mathrm{L}$ in wine (red wine: $17.0 \pm 4.17 \mu \mathrm{g} / \mathrm{L}$; white wine: $8.3 \pm 1.66 \mu \mathrm{g} \mathrm{Li} / \mathrm{L}$ ) was slightly lower than previously reported values of 44 to $58 \mu \mathrm{g} \mathrm{Li} / \mathrm{L}$ in Spanish or Californian wines $[37,38]$. Only three of the analysed red wine samples revealed similar values of $48.1,45.0$ and $43.6 \mu \mathrm{g} \mathrm{Li} / \mathrm{L}$, which may be related to a high Li concentration in the soil. Wines from Germany exhibited rather low Li concentrations (on average $7.4 \mu \mathrm{g} \mathrm{Li} / \mathrm{L}$ ).

The Li content of the tested beers $(8.5 \pm 0.77 \mu \mathrm{g} \mathrm{Li} / \mathrm{L})$ was relatively low, which may be due to the beer production process. For beer production purposes, brewing water is usually demineralized to a certain extent [39], which may result in considerable losses of trace elements, including Li.

In comparison to our study in mineral waters comprising almost 400 samples, the sample size of the present study was lower and should be extended in the future considering additional beverage categories such as fruit juice and milk [40], taking regional differences into account. Furthermore, the sample size of the wine category should be significantly increased considering also representative samples from other countries. Voica and coworkers recently determined Li levels in food from the Romanian market, comprising over 200 samples. Interestingly, vegetable samples exhibited the highest Li concentration followed by dairy products [41]. Based on our and literature data, we suggest an open source Li food database that could be an important resource for consumers and stakeholders as well as 
nutritionists and dieticians. Furthermore, studies are needed to address the extent to which the food matrix and dietary constituents (e.g., calcium, phosphate, tannic acid) may modulate Li bioavailability in humans [42].

\subsection{Studies in Flies}

The fruit fly Drosophila melanogaster has been increasingly recognised as a model organism to study absorption mechanisms, bioavailability, and function of trace elements including Li [43-45]. Therefore, in addition to the $\mathrm{Li}$ analysis of 160 beverages, we performed a pilot feeding study in Drosophila melanogaster to determine whether $\mathrm{Li}$ from beverages is bioavailable in vivo. In accordance with an already published bioavailability study in humans [20], fly medium was prepared with three different mineral waters containing low, medium and high Li concentrations. Additionally, we prepared five different fly media by replacing the liquid fraction with the respective beverage containing the highest amount of Li within its beverage category. After seven days of feeding, the Li accumulation in the flies fed the beverage containing SY media was compared to Li accumulation in flies on SY medium prepared with deionized water (Figure 2).

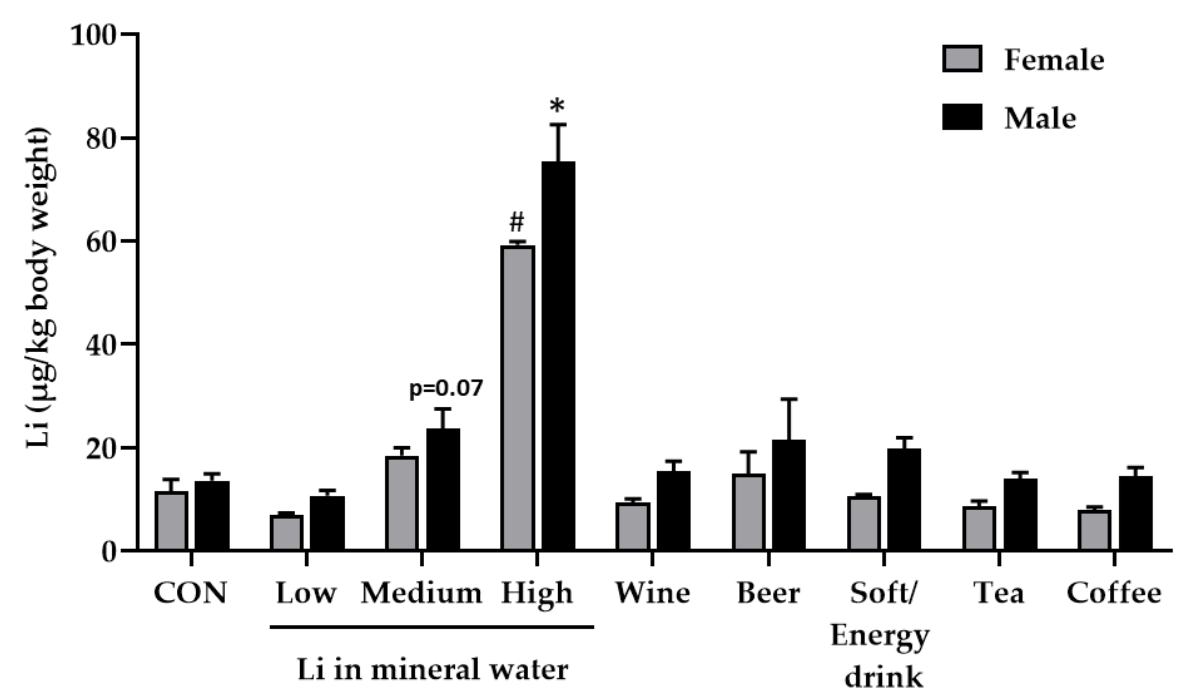

Figure 2. Effect of diets prepared with different beverages on lithium (Li) accumulation in fly bodies. The flies received a sugar yeast diet prepared with deionised water (CON) and eight beverages, including three different mineral waters comprising low, medium and high Li concentrations as well as wine, beer, soft/energy drink, tea and coffee. The Li accumulation in female and male flies was measured by inductively coupled plasma mass spectrometry (ICP-MS). Data are shown as the means \pm SEM ( $n=4-8$ independent experiments per group, comprising 100 flies/group). Since the data of both sexes were positively skewed, they were inversely transformed, and a Games-Howell post hoc test was conducted. * Indicates significant differences compared to the control in males $(p<0.05)$; \# Indicates significant differences compared to the control in females $(p \leq 0.05)$.

Only mineral water containing a high Li concentration $(\sim 1600 \mu \mathrm{g} / \mathrm{L})$ significantly increased whole-body Li retention in female and male flies (Figure 2). The mineral water with medium Li content $(\sim 200 \mu \mathrm{g} / \mathrm{L})$ at least tended to increase body Li levels in male flies $(p=0.07)$. Tea and coffee infusions, the soft/energy drink, beer and wine did not affect whole-body Li retention of the flies. Besides the absolute Li concentration of beverages, the impact of further ingredients as modulator of the Li status should be also taken into account. This includes other minerals and trace elements as well as alkaloids and phenolic compounds to name a few. For example, Li-rich mineral waters are often rich in sodium, potassium and magnesium [20]. It should be considered that these minerals may also affect $\mathrm{Li}$ absorption, elimination and bioactivity in flies. Moreover, negatively charged phenolic compounds found in tea, coffee, beer and wine might reduce Li accumulation in the fly body via Li chelation and/or 
increased excretion. As shown by Erdemir and Gucer, tannic acid reduces the bioaccessibility of Li from tea in an in vitro digestion model [42].

Additional studies in flies providing purified $\mathrm{Li}$ (e.g., $\mathrm{LiCl}$ ) should be performed to elucidate critical dietary Li concentrations sufficient to modulate Li-sensitive targets, including an inactivation of glycogen synthase kinase 3ß (Gsk3ß) [14,46]. Beside Gsk3ß, other Li sensitive targets including the transcription factor nuclear factor erythroid 2-related factor 2 (Nrf2) have been identified in Drosophila melanogaster [14,47]. Nrf2 target genes exhibit cytoprotective properties which may be important in prevention of stress-related disorders such as Alzheimer's or Parkinson's disease [48]. The vast majority of studies published in the literature on the role of Li on Drosophila melanogaster phenotypes administered very high pharmacological $\mathrm{Li}$ concentration in the millimolar range $[14,45,49,50]$. Thus, these pharmacological Li concentrations were manifold higher than the Li concentrations as provided in the present feeding study. It is unknown of what extent low dietary Li concentrations affect Drosophila phenotypes including survival, body composition, stress response, circadian rhythm and sleep, locomotor function and cognition, which warrants further investigations. Pharmacological $\mathrm{Li}$ treatments are known to exhibit side effects (e.g., impairment of kidney and thyroid function), a relatively poor tolerance and a small therapeutic window in humans [51,52]. In contrary, dietary $\mathrm{Li}$ is supposed to be safe and well tolerated for human consumption [41]. Nevertheless, the exact molecular function of dietary $\mathrm{Li}$ as a potential essential trace element has yet not been fully elucidated. Due to the provision of basically Li-free holidic diets to Drosophila melanogaster it may be possible to pinpoint a critical concentration in terms of Li bioactivity and also to identify novel Li-sensitive targets in future studies. We suggest that the current experimental approach of our pilot study combining results from a food database with the Li status in the model organism Drosophila melanogaster could be also expanded to other minerals and trace elements. Nevertheless, a limitation of our study is that we determined only whole-body Li retention. However, we did not measure Li distribution in different tissues of the fly, such as the head. Kasuya et al. (2009) demonstrated that high Li concentrations (50 $\mathrm{mmol} / \mathrm{L} \mathrm{Li}$ in the diet) significantly affected differential gene expression profiles in Drosophila heads [49]. Accordingly, data from Farha et al. suggest that high dose Li changes genes expression profiles in murine brain which may be highly relevant to its neuroprotective properties [53].

In the present study, flies were fed experimental diets, containing different Li concentrations, only for seven days. The average life span of Drosophila is around 60 (males) to 80 (females) days [23]. Therefore, it would be interesting to investigate whether a chronic or even life-long dietary Li supplementation may result in a substantial Li tissue accumulation. Currently, the underlying mechanisms of Li homeostasis in Drosophila melanogaster including putative Li transporters are largely unknown. Furthermore, we conducted our feeding studies only in the Drosophila strain $w^{1118}$. It is unclear whether other Drosophila strains such as Canton or Oregon react similarly in terms of Li whole body retentions in response to a varying dietary Li supply.

From a nutritional point of view, Li status and Li excretion should be systematically monitored in the general population and correlated with robust dietary, anthropometric, biochemical and clinical read outs. We suggest that our present data may be helpful for evaluating Li intake via beverages in the German population. However, we are also aware of the fact that the Li concentrations of the 160 mainly German beverages, as measured within in the study, cannot fully transferred to other countries because of considerable regional differences mainly related to differences in the Li level of the soil $[21,54]$. Finally, systematic studies are needed to address the question which foods may contribute to a positive Li balance in humans taking also regional differences in the Li concentration of foods into account. Overall, the present data suggest that unlike Li-rich mineral water, and most but not all tea, coffee, soft and energy drinks, beer and wine samples are rather poor in Li. It needs to be established whether, and to what extent, these different beverages contribute to the Li supply and Li bioactivity in humans. 
Author Contributions: All of the authors contributed significantly to the research. Conceptualization: U.S., M.B., K.L., I.R.I., G.R.; Methodology: U.S., K.J., N.H., M.B.; Formal Analysis: U.S., K.J., N.H., I.R.I.; Data Curation: U.S., I.R.I.; Writing-Original: U.S., G.R.; Writing-Review\&Editing: All authors; Supervision: M.B., G.R.; Project administration: U.S., M.B., G.R.; Funding acquisition: M.B. All authors have read and agreed to the published version of the manuscript.

Funding: M.B. received funding from the internal research fund of the University of Applied Sciences Fulda.

Acknowledgments: We thank the students research group "BioList" for technical assistance. We acknowledge financial support by the German Research Foundation (DFG) within the funding program "Open Access Publication".

Conflicts of Interest: The authors declare no conflict of interest. The funders had no role in the design of the study; in the collection, analyses, or interpretation of data; in the writing of the manuscript, or in the decision to publish the results.

\section{References}

1. Statista GmbH. Per Capita Consumption of Beverages in Germany from 2003 to 2018, By Type. 2019. Available online: https://www.statista.com/statistics/508273/beverages-per-capita-consumption-by-type-germany/ (accessed on 10 March 2020).

2. Elmadfa, I.; Meyer, A.L. Patterns of Drinking and Eating Across the European Union: Implications for Hydration Status. Nutr. Rev. 2015, 73, 141-147. [CrossRef] [PubMed]

3. Darret, G.; Couzy, F.; Antoine, J.-M.; Magliola, C.; Mareschi, J.-P. Estimation of Minerals and Trace Elements Provided by Beverages for the Adult in France. Ann. Nutr. Metab. 1986, 30, 335-344. [CrossRef] [PubMed]

4. Styburski, D.; Dec, K.; Baranowska-Bosiacka, I.; Goschorska, M.; Hołowko, J.; Żwierełł, W.; Skórka-Majewicz, M.; Janda, K.; Rosengardt, A.; Gutowska, I. Can Functional Beverages Serve as a Substantial Source of Macroelements and Microelements in Human Nutrition?-Analysis of Selected Minerals in Energy and Isotonic Drinks. Boil. Trace Elem. Res. 2019, 1-8. [CrossRef] [PubMed]

5. Donix, M.; Bauer, M. Population Studies of Association Between Lithium and Risk of Neurodegenerative Disorders. Curr. Alzheimer Res. 2016, 13, 1. [CrossRef]

6. Kessing, L.V.; Gerds, T.A.; Knudsen, N.N.; Jørgensen, L.F.; Kristiansen, S.; Voutchkova, D.; Ernstsen, V.; Schullehner, J.; Hansen, B.; Andersen, P.K.; et al. Association of Lithium in Drinking Water With the Incidence of Dementia. JAMA Psychiatry 2017, 74, 1005-1010. [CrossRef]

7. Matsunaga, S.; Kishi, T.; Annas, P.; Basun, H.; Hampel, H.; Iwata, N. Lithium as a Treatment for Alzheimer's Disease: A Systematic Review and Meta-Analysis. J. Alzheimer's Dis. 2015, 48, 403-410. [CrossRef]

8. Schöpfer, J.; Schrauzer, G.N. Lithium and Other Elements in Scalp Hair of Residents of Tokyo Prefecture as Investigational Predictors of Suicide Risk. Boil. Trace Elem. Res. 2011, 144, 418-425. [CrossRef]

9. Goldstein, M.R.; Mascitelli, L. Is Violence in Part a Lithium Deficiency State? Med. Hypotheses 2016, 89, 40-42. [CrossRef]

10. Smith, K.A.; Cipriani, A. Lithium and Suicide in Mood Disorders: Updated Meta-Review of the Scientific Literature. Bipolar Disord. 2017, 19, 575-586. [CrossRef]

11. Liu, B.; Wu, Q.; Zhang, S.; Del Rosario, A. Lithium Use and Risk of Fracture: A Systematic Review and Meta-Analysis of Observational Studies. Osteoporos. Int. 2018, 30, 257-266. [CrossRef]

12. Jung, S.; Koh, J.; Kim, S.; Kim, K. Effect of Lithium on the Mechanism of Glucose Transport in Skeletal Muscles. J. Nutr. Sci. Vitaminol. 2017, 63, 365-371. [CrossRef] [PubMed]

13. Zarse, K.; Terao, T.; Tian, J.; Iwata, N.; Ishii, N.; Ristow, M. Low-Dose Lithium Uptake Promotes Longevity in Humans and Metazoans. Eur. J. Nutr. 2011, 50, 387-389. [CrossRef] [PubMed]

14. Castillo-Quan, J.I.; Li, L.; Kinghorn, K.J.; Ivanov, D.; Tain, L.S.; Slack, C.; Kerr, F.; Nespital, T.; Thornton, J.; Hardy, J.; et al. Lithium Promotes Longevity through GSK3/NRF2-Dependent Hormesis. Cell Rep. 2016, 15, 638-650. [CrossRef] [PubMed]

15. Hayslett, J.P.; Kashgarian, M. A Micropuncture Study of the Renal Handling of Lithium. Pflüg. Arch. Eur. J. Physiol. 1979, 380, 159-163. [CrossRef]

16. Thomas, L.; Xue, J.; Rieg, T.; Rieg, T. Contribution of NHE3 and Dietary Phosphate to Lithium Pharmacokinetics. Eur. J. Pharm. Sci. 2019, 128, 1-7. [CrossRef]

17. Uwai, Y.; Arima, R.; Takatsu, C.; Furuta, R.; Kawasaki, T.; Nabekura, T. Sodium-Phosphate Cotransporter Mediates Reabsorption of Lithium in Rat Kidney. Pharmacol. Res. 2014, 87, 94-98. [CrossRef] 
18. Figueroa, L.; Barton, S.; Schull, W.; Young, A.; Kamiya, Y.; Hoskins, J.; Ilgren, E. Environmental Lithium Exposure in the North of Chile - Tissue exposure indices. Epidemiol. Biostat. Public Health 2014, 11, e8847-1.

19. Baloch, S.; Kazi, T.G.; Baig, J.A.; Talpur, F.N.; Arain, M.B.; Afridi, H.I. Correlation of Lithium Levels Between Drinking Water Obtained from Different Sources and Scalp Hair Samples of Adult Male Subjects. Environ. Geochem. Health 2016, 39, 1191-1199. [CrossRef]

20. Seidel, U.; Baumhof, E.; Hägele, F.A.; Bosy-Westphal, A.; Birringer, M.; Rimbach, G. Lithium-Rich Mineral Water is a Highly Bioavailable Lithium Source for Human Consumption. Mol. Nutr. Food Res. 2019, 63, e1900039. [CrossRef]

21. Schrauzer, G.N. Lithium: Occurrence, Dietary Intakes, Nutritional Essentiality. J. Am. Coll. Nutr. 2002, 21, 14-21. [CrossRef]

22. Szklarska, D.; Rzymski, P. Is Lithium a Micronutrient? From Biological Activity and Epidemiological Observation to Food Fortification. Boil. Trace Elem. Res. 2018, 189, 18-27. [CrossRef]

23. Staats, S.; Lüersen, K.; Wagner, A.E.; Rimbach, G. Drosophila Melanogaster as a Versatile Model Organism in Food and Nutrition Research. J. Agric. Food Chem. 2018, 66, 3737-3753. [CrossRef]

24. Lüersen, K.; Röder, T.; Rimbach, G. Drosophila Melanogaster in Nutrition Research-The Importance of Standardizing Experimental Diets. Genes Nutr. 2019, 14, 3. [CrossRef]

25. Wagner, A.E.; Piegholdt, S.; Rabe, D.; Baenas, N.; Schloesser, A.; Eggersdorfer, M.; Stocker, A.; Rimbach, G. Epigallocatechin gallate Affects Glucose Metabolism and Increases Fitness and Lifespan in Drosophila Melanogaster. Oncotarget 2015, 6, 30568-30578. [CrossRef] [PubMed]

26. Ashburner, M. Drosophila: A Laboratory Manual; Cold Spring Harbor Laboratory: New York, NY, USA, 1989.

27. Bellivier, F.; Marie-Claire, C. Molecular Signatures of Lithium Treatment: Current Knowledge. Pharmacopsychiatry 2018, 51, 212-219. [CrossRef] [PubMed]

28. Rzymski, P.; Niedzielski, P.; Siwulski, M.; Mleczek, M.; Budzyńska, S.; Gąsecka, M.; Poniedziałek, B. Lithium Biofortification of Medicinal Mushrooms Agrocybe cylindracea and Hericium erinaceus. J. Food Sci. Technol. 2017, 54, 2387-2393. [CrossRef] [PubMed]

29. Jiang, L.; Wang, L.; Tanveer, M.; Tian, C. Lithium Biofortification of Medicinal Tea Apocynum venetum. Sci. Rep. 2019, 9, 8182. [CrossRef] [PubMed]

30. Wang, L.; Jiang, L.; Zhao, Z.-Y.; Tian, C.-Y. Lithium Content of Some Teas and their Infusions Consumed in China. Food Sci. Biotechnol. 2013, 23, 323-325. [CrossRef]

31. Kavanagh, L.; Keohane, J.; Cabellos, G.G.; Lloyd, A.; Cleary, J. Global Lithium Sources-Industrial Use and Future in the Electric Vehicle Industry: A Review. Resources 2018, 7, 57. [CrossRef]

32. El-Mallakh, R.S.; Roberts, R.J. Lithiated Lemon-Lime Sodas. Am. J. Psychiatry 2007, 164, 1662. [CrossRef] [PubMed]

33. El-Mallakh, R.S.; Jefferson, J.W. Prethymoleptic Use of Lithium. Am. J. Psychiatry 1999, 156, 129. [CrossRef] [PubMed]

34. Nomani, H.; Moghadam, A.T.; Emami, S.A.; Mohammadpour, A.H.; Johnston, T.P.; Sahebkar, A. Drug Interactions of Cola-containing Drinks. Clin. Nutr. 2019, 38, 2545-2551. [CrossRef] [PubMed]

35. Kralovec, K.; Fartacek, R.; Ploderl, M.; Fartacek, C.; Aichhorn, W. Low Serum Lithium Associated With Immoderate Use of Coca-Cola Zero. J. Clin. Psychopharmacol. 2011, 31, 543-544. [CrossRef] [PubMed]

36. Santos, V.; Teixeira, G.H.D.A.; Barbosa, F.; Barbosa, F. Açaí (Euterpe oleraceaMart.): A Tropical Fruit with High Levels of Essential Minerals-Especially Manganese-And its Contribution as a Source of Natural Mineral Supplementation. J. Toxicol. Environ. Health Part A 2014, 77, 80-89. [CrossRef]

37. Cox, R.J.; Eitenmiller, R.R.; Powers, J.J. Mineral Content of Some California Wines. J. Food Sci. 1977, 42, 849-850. [CrossRef]

38. Núñez, M.; Peña, R.M.; Herrero, C.; García, S. Determination of Six Metals in Galician Red Wines (in Northwestern Spain) by Capillary Electrophoresis. J. AOAC Int. 2000, 83, 183-188. [CrossRef]

39. Eumann, M.; Schildbach, S. 125th Anniversary Review: Water Sources and Treatment in Brewing. J. Inst. Brew. 2012, 118, 12-21. [CrossRef]

40. Hocaoglu-Emre, F.S. ICP-MS Analysis of Trace Element Concentrations in Cow's Milk Samples from Supermarkets in Istanbul, Turkey. Boil. Trace Elem. Res. 2019, 193, 166-173. [CrossRef]

41. Voica, C.; Roba, C.; Iordache, A.M. Lithium Levels in Food from the Romanian Market by Inductively Coupled Plasma-Mass Spectrometry (ICP-MS): A Pilot Study. Anal. Lett. 2020, 16, 1-13. [CrossRef] 
42. Erdemir, U.; Gucer, S. Correlation of Lithium Bioaccessibility From Tea (Camellia sinensis L.) with Tea Type and Consumption Habits. Food Chem. 2018, 244, 364-370. [CrossRef]

43. Yin, S.; Qin, Q.; Zhou, B. Functional Studies of Drosophila Zinc Transporters Reveal the Mechanism for Zinc Excretion in Malpighian Tubules. BMC Boil. 2017, 15, 12. [CrossRef] [PubMed]

44. Navarro, J.A.; Schneuwly, S. Copper and Zinc Homeostasis: Lessons from Drosophila Melanogaster. Front. Genet. 2017, 8, 223. [CrossRef]

45. E Dokucu, M.; Yu, L.; Taghert, P.H. Lithium- and Valproate-Induced Alterations in Circadian Locomotor Behavior in Drosophila. Neuropsychopharmacology 2005, 30, 2216-2224. [CrossRef] [PubMed]

46. Fenech, R.K.; Ryan, C.R.; Roy, B.; Fajardo, V.A.; MacPherson, R.E.K. GSK3 Activity is Decreased in The Hippocampus of Male Mice Supplemented with Low-Dose Lithium in Drinking Water. FASEB J. 2020, 34, 1. [CrossRef]

47. Kerr, F.; Sofola-Adesakin, O.; Ivanov, D.; Gatliff, J.; Perez-Nievas, B.G.; Bertrand, H.C.; Martínez, P.; Callard, R.; Snoeren, I.; Cochemé, H.M.; et al. Direct Keap1-Nrf2 Disruption as a Potential Therapeutic Target for Alzheimer's Disease. PLoS Genet. 2017, 13, e1006593. [CrossRef]

48. Niture, S.K.; Khatri, R.; Jaiswal, A.K. Regulation of Nrf2-an Update. Free. Radic. Boil. Med. 2013, 66, 36-44. [CrossRef]

49. Kasuya, J.; Kaas, G.; Kitamoto, T. Effects of Lithium Chloride on the Gene Expression Profiles in Drosophila Heads. Neurosci. Res. 2009, 64, 413-420. [CrossRef]

50. Kasuya, J.; Kaas, G.A.; Kitamoto, T. A Putative Amino Acid Transporter of the Solute Carrier 6 Family is Upregulated by Lithium and is Required for Resistance to Lithium Toxicity in Drosophila. Neuroscience 2009, 163, 825-837. [CrossRef]

51. Pisanu, C.; Melis, C.; Squassina, A.; Gurwitz, D. Lithium Pharmacogenetics: Where Do We Stand? Drug Dev. Res. 2016, 77, 368-373. [CrossRef]

52. Gitlin, M.J. Lithium Side Effects and Toxicity: Prevalence and Management Strategies. Int. J. Bipolar Disord. 2016, 4, 27. [CrossRef]

53. Farah, R.; Khamisy-Farah, R.; Amit, T.; Youdim, M.B.H.; Arraf, Z. Lithium's Gene Expression Profile, Relevance to Neuroprotection A cDNA Microarray Study. Cell. Mol. Neurobiol. 2013, 33, 411-420. [CrossRef] [PubMed]

54. Kabata-Pendias, A. Trace Elements in Soils and Plants, 4th ed.; CRC Press: Boca Raton, FL, USA, 2011; ISBN 9781420093681.

(C) 2020 by the authors. Licensee MDPI, Basel, Switzerland. This article is an open access article distributed under the terms and conditions of the Creative Commons Attribution (CC BY) license (http://creativecommons.org/licenses/by/4.0/). 